УдК 342.56

\title{
Т.И. Ряховская
}

\section{ДЕЯТЕЛЬНОСТЬ КОНСТИТУЦИОННОГО СУДА РФ В СФЕРЕ ОБЕСПЕЧЕНИЯ ПРЯМОГО ДЕЙСТВИЯ КОНСТИТУЦИИ МЕРАМИ ОХРАНЫ}

\begin{abstract}
Статья посвящена проблемам теоретико-методологических основ прямого действия Конституции. В рамках исследования осуществлен анализ деятельности Конституционного Суда РФ в сфере обеспечения прямого действия Конституции РФ и, в первую очередь, представлена идея об обеспечении им прямого действия Конституции РФ мерами охраны, что проиллюстрировано некоторыми примерами из практики. Проанализированы постановления Конституционного Суда РФ о толковании Конституции РФ и предложен вывод.

Ключевые слова: Конституция РФ; прямое действие Конституции РФ; Конституционный Суд; юридические свойства конституции; правовая деятельность; охрана Конституции; система обеспечения прямого действия Конституции.
\end{abstract}

Вопрос о прямом действии норм Конституции РФ по-прежнему остается дискуссионным и актуальным, что связано с обсуждением предложений, касающихся внесения изменений в Основной закон государства, а также отсутствием юридического закрепления расшифровки указанного термина.

Полагаем, прямое действие Конституции Российской Федерации - это юридическое свойство норм Основного закона, имеющее легальный характер, выражающее правило действия и реализации конституционно-правовых норм независимо от наличия конкретизирующих их нормативно-правовых актов. В целях наиболее эффективной реализации прямого действия Конституции Российской Федерации предлагается ввести термин «система обеспечения прямого действия Конституции», включающий в себя взаимосвязанные формы правовой деятельности публичных органов государственной власти и местного самоуправления, направленные на реализацию свойства прямого действия Конституции. Существование системы обеспечения прямого действия Конституции обусловливается совокупностью юрисдикций органов власти различных уровней, их взаимосвязью, структурой самой Конституции, выражающейся в согласованности конституционных положений, определяющих концептуальное единство последней.

Применительно к системе обеспечения прямого действия Конституции РФ ее базовыми элементами являются: правовая деятельность органов государственной власти, местного самоуправления, граждан (как представителей гражданского общества) в форме охраны прямого действия Конституции и их правовая деятельность в форме его защиты.

Существуют различные подходы к разграничению понятий охраны и защиты Конституции РФ; не ставя целью исследования их разграничение, обращаясь к накопленному опыту ученых по этому вопросу, присоединимся к идее Д.А. Авдеева, высказанной в контексте разграничения терминов «охрана» и «защита» прав и свобод человека и гражданина [1. С. 11]. И предположим, что в контексте системы обеспечения прямого действия Конституции РФ правовая деятельность в форме охраны может быть расшифрована как взаимосвязанные меры, осуществляемые органами государственной власти и местного самоуправления, общественными организациями, гражданами, направленные на предупреждение нарушений положений конституционно-правовых норм и способствование их процессу реализации.

Особый же интерес к правовой деятельности Конституционного Суда в системе обеспечения прямого действия Конституции РФ обусловлен его специфической правовой природой, основными чертами которой являются следующие существенные характеристики: правовой статус - судебный орган; функции осуществление конституционного контроля; главные принципы деятельности - самостоятельное и независимое осуществление судебной власти; процессуальная форма деятельности - конституционное судопроизводство [2. С. 58-60]. Более того, по мнению Б.С. Эбзеева, Конституционный Суд РФ является гарантом политического мира в обществе и государстве [3. С. 6].

Как справедливо отмечает Н.С. Бондарь, разрешая конкретные дела о конституционности оспариваемых законодательных положений и тем более осуществляя непосредственное толкование Основного закона, Конституционный Суд РФ раскрывает содержание конституционных норм, оценивает проверяемые положения отраслевого законодательства в их системной взаимосвязи, одновременно утверждая на основе конституционных императивов верховенство и прямое действие Конституции РФ (ст. 15), непосредственность действия и самих по себе прав и свобод человека и гражданина (ст. 18) - как для законодателя, так и для всех правоприменителей [4. С. 4-5].

Т.И. Алиев и Е.В. Бердникова предлагают считать, что Конституционный Суд РФ по отношению к Конституции играет двоякую роль: как институционального гаранта, позволяющего реализовать свойство юридического верховенства Основного закона страны и осуществлять его правовую охрану, а также как органа, фактически наделенного правом нетекстового преображения конституционных норм [5. С. 13]. Полагаем, это весьма справедливо. Своей деятельностью в сфере толкования Конституции РФ Конституционный Суд обеспечивает не только ее прямое действие, но и устойчивость, внося корректировки своим правовыми позициями, подстраивая базовый текст под современные реалии, не меняя его сущности. В этом и заключается идея обеспечения прямого действия Конституции РФ мерами охраны.

Таким образом, Конституционный Суд РФ занимает особое место в системе обеспечения прямого 
действия Конституции как специализированный орган конституционного контроля, созданный с целью обеспечения прямого действия Конституции, причем, несмотря на то что законодательно закреплено лишь его полномочие осуществлять защиту прямого действия Конституции, этот орган осуществляет и ее правовую охрану, что справедливо отмечает С.А. Савченко [6. С. 355-356]. Давая официальное нормативное толкование Конституции РФ, Конституционный Суд РФ обеспечивает условия для наиболее полной реализации ее положений.

Конституция РФ и ФКЗ «О Конституционном Суде РФ» отделили официальное нормативное толкование от других категорий дел, которые вправе разрешать Конституционный Суд РФ. Поводом для толкования является неопределенность норм Конституции, которую в науке предлагается понимать как нарушение качества закона, требований, предъявляемых к нему, в частности точности и ясности формулировок. Именно анализ лексики Конституции РФ, выявление оттенков значений слов, терминов и терминологических оборотов позволяют правильно понять смысл правовых положений, избежав тем самым ошибок в процессе законотворчества и правоприменения. По проблеме, связанной с пределами и границами толкования Судом конституционных норм, нет однозначного решения. По нашему мнению, Конституционный Суд ограничен в первую очередь конституционными нормами, которые имеют «презумпцию». Кроме того, здесь нельзя исключать еще и самоограничение рассматриваемого нами органа государственной власти, т.е. при любой своей деятельности он не вправе подменять законодателя. Однако, если речь идет об отсутствии какой-либо нормы, то, на наш взгляд, Суд имеет право временного устранения пробела с условием, что впоследствии необходимый для регулирования конкретных отношений правовой акт будет принят. Сам Конституционный Суд неоднократно выражал свою позицию об отсутствии намерения подменять законодателя, что впервые установлено в Определении от 20 ноября 1995 г. № 77-О [7].

Вместе с тем имеются и примеры проявления правотворческих функций Суда, например дело о толковании ст. 136 Конституции РФ, где Конституционный Суд установил, что из предусмотренной Конституцией РФ процедуры принятия поправок к гл. 3-8 вытекает, что поправки в смысле ст. 136 принимаются в форме особого правового акта - Закона РФ о поправке к Конституции РФ [8], который, по идее, нигде не предусмотрен.

За период 1995-2015 гг. Конституционным Судом толковались положения ст. 91 и 92 (ч. 2); 84 (п. «б»); 99 (ч. 1, 2 и 4); 109 (ч. 1); 92 (ч. 2 и 3); 71 (п. «Г»); 76 (ч. 1); 112 (ч. 1); 111 (ч. 4); 125-127; 66 (ч. 4); 107; 137 (ч. 2); $136 ; 103$ (ч. 3); 105 (ч. 2 и 5); 107 (ч. 3); 108 (ч. 2); 117 (ч. 3); 125 (ч. 2); 105 (ч. 4), 106 и др., где основное место занимали дела, связанные с законодательным процессом. (Всего же постановлений о толковании норм Конституции за указанный период было принято 13 [9], что говорит не только о малой востребованности этой процедуры, но и об отсутствии неопределенности норм Основного закона.)
Вместе с тем деятельность Конституционного Суда практически всегда соприкасается с другими видами государственной деятельности, подчиняя их необходимости следовать высшему закону государства Конституции РФ, обладающей прямым действием.

Конституционный Суд интерпретировал и толковал в соответствии с доктриной и логикой Основного закона многие конституционные положения о новом федерализме, организующей роли центра и равноправии субъектов Федерации, организации региональной государственной власти и местного самоуправления. Есть ряд объективных и субъективных причин, обусловивших эти процессы: 1) переход на прямое и непосредственное применение Конституции Российской Федерации; 2) отставание законодательного процесса от реального хода социально-экономических и политических преобразований, пробельность и противоречивость действующего федерального законодательства; 3) трудности становления и развития регионального законодательства, проблемы, связанные с реализацией функции законодательствования в отдельных субъектах [10. С. 264-265]. Бесспорно, в таких условиях положительные результаты деятельности Конституционного Суда сложно переоценить.

Например, проблема, ставшая предметом разбирательства в Конституционном Суде, возникла в связи с коллизией, заключенной в Конституции РФ: с одной стороны, автономным округам придается статус равноправных субъектов Федерации (ч. 1, 4 ст. 5), а с другой - сохраняется их включенность в состав другого образования - края или области [11. С. 85]. Свою правовую позицию, выраженную в Постановлении от 14.07.1997 № 12-П, Конституционный Суд основывал на том, что вхождение автономного округа в состав края, области по смыслу ч. 4 ст. 66 Конституции РФ означает такое конституционное состояние, при котором автономный округ, будучи равноправным субъектом России, одновременно составляет часть другого субъекта РФ - края или области. Однако вхождение не умаляет статуса автономного округа как равноправного субъекта Российской Федерации, поскольку он вправе по своему усмотрению распоряжаться тем объемом полномочий, которые предоставлены ему Конституцией РФ [12]. Обозначенное имеет общее значение, распространятся на все автономные округа, входящие в состав края, области.

Конституционный Суд при официальном нормативном толковании должен учитывать приоритет основ конституционного строя. Вместе с тем интересным представляется и мнение самого Суда по этому поводу, которое выражено в различных определениях, содержащих правовые позиции. Например, Государственная Дума требовала признать недействующим положение ч. 2 ст. 95 Конституции Российской Федерации в части, противоречащей принципу разделения властей, на что обращающиеся получили ответ: «В компетенцию Конституционного Суда Российской Федерации, установленную статьей 125 Конституции Российской Федерации и статьей 3 Федерального конституционного закона "О Конституционном Суде Российской Федерации”, не входит проверка конституционности конституционных положений, призна- 
ние их недействующими, утратившими силу» [13]. Похожими формулировками наполнены и иные определения, содержащие в себе отказы о принятии к рассмотрению: «Конституционный Суд не вправе проверять конституционность Конституции Российской Федерации ни по каким параметрам» [14].

По верному замечанию В.Д. Зорькина, официальное, общеобязательное толкование Конституции Конституционным Судом служит для преодоления имеющихся неконституционных положений в законодательстве, тем самым обеспечивая охрану Конституции и ориентируя правотворчество, правоприменение и всю сеть конкретных правоотношений на положения Конституции, являющиеся, в свою очередь, нормативной основой постоянно меняющегося мира. И в данном контексте именно пу- тем интерпретации норм Основного закона возможно обеспечение стабильности и динамизма общества [15. С. 27-28].

Таким образом, обеспечение прямого действия Конституции РФ мерами охраны имеет важнейшее значение. Это не абстрактная деятельность, а вполне конкретная, результатом которой является предотвращение нарушения принципа прямого действия Конституции РФ. Рассмотренная правовая деятельность Конституционного Суда РФ в этой сфере связана с конкретизацией и уяснением смысла конституционных положений. А главным критерием построения этой «надстройки» Конституции РФ являются сами ее нормы, в которых закреплены: 1) основные положения, которым требуется дополнительное развитие; 2) основные направления такого развития.

\section{ЛИТЕРАТУРА}

1. Авдеев Д.А. Правовой механизм обеспечения прав и свобод человека и гражданина : автореф. дис. ... канд. юрид. наук. Тюмень, 2004. $20 \mathrm{c}$

2. Кряжков В.А., Лазарев Л.В. Конституционная юстиция в Российской Федерации : учеб. пособие. М. : Изд-во БЕК, 1998. 462 с.

3. Эбзеев Б.С. Конституционный Суд Российской Федерации: новая страница жизни // Человек и закон. 1994. № 11. С. 3-12.

4. Бондарь Н.С. Решения Конституционного Суда как мера свободы и ответственности // Конституционное и муниципальное право. 2006. № 10. С. 2-5.

5. Алиев Т.И., Бердникова Е.В. Конституция Российской Федерации: пределы стабильности и перспективы модернизации // Современное право. 2013. № 12. С. 9-14.

6. Савченко С.А. Конституционный процесс реализации норм, закрепляющих основы конституционного строя России. Тюмень : Изд-во ТюмГУ, 2011. 464 с

7. Определение Конституционного Суда РФ от 20 ноября 1995 г. № 77-О «Об отказе в принятии к рассмотрению запроса группы депутатов Государственной Думы Федерального Собрания и запроса Верховного Суда Российской Федерации о проверке конституционности ряда положений Федерального закона от 21 июня 1995 года “О выборах депутатов Государственной Думы Федерального Собрания Российской Федерации”» // СЗ РФ. 1995. № 49. Ст. 4867.

8. Постановление Конституционного Суда РФ от 31 октября 1995 г. № 12-П «По делу о толковании статьи 136 Конституции Российской Федерации» // С3 РФ. 1995. № 45. Ст. 4408 (Комментарий: Кутафин О.Е. Предмет конституционного права. М. : Юристь, 2001. С. 149).

9. URL: http://www.ksrf.ru/ru/Decision/Statisticses/Pages/Decision.aspx (дата обращения: 9.04.2016).

10. Митюков М.А., Барнашов А.М. Очерки конституционного правосудия (сравнительно-правовое исследование законодательства и судебной практики). Томск : Изд-во Том. ун-та, 1999. 405 с.

11. Комментарий к постановлениям Конституционного Суда Российской Федерации / отв. ред. Б.С. Эбзеев : в 2 т. М. : Юристъ, 2000. Т. 1: Государственная власть. Местное самоуправление. $651 \mathrm{c.}$

12. Постановление Конституционного Суда РФ от 14 июля 1997 г. № 12-П «По делу о толковании содержащегося в части 4 статьи 66 Конституции Российской Федерации положения о вхождении автономного округа в состав края, области» // С3 РФ. 1997. № 29. Ст. 3581.

13. Определение Конституционного Суда от 28 декабря 1995 г. № 137-О «Об отказе в принятии к рассмотрению запроса Государственной Думы Федерального Собрания о толковании положений статьи 80 и части 2 статьи 95 Конституции Российской Федерации» // СПС «Гарант» (текст определения официально опубликован не был).

14. Определение Конституционного Суда РФ от 1 апреля 1996 г. № 13-О «Об отказе в принятии к рассмотрению запроса группы депутатов Государственной Думы Федерального Собрания о проверке конституционности Указа Президента Российской Федерации от 15 октября 1993 года № 1633 “О проведении всенародного голосования по проекту Конституции Российской Федерации” в части утверждения Положения о всенародном голосовании по проекту Конституции Российской Федерации 12 декабря 1993 года» // Лазарев Л.В. Правовые позиции Конституционного Суда России. М. : ОАО Издательский дом «Городец»; Формула права, 2003. С. 131 (текст определения официально опубликован не был).

15. Зорькин В.Д. Конституционно-правовое развитие России. М. : Норма; ИНФРА-М, 2011.720 с.

Статья представлена научной редакцией «Право» 24 марта 2017 г.

\section{THE CONSTITUTIONAL COURT OF THE RUSSIAN FEDERATION ON ENSURING THE DIRECT ACTION OF THE CONSTITUTION BY SECURITY MEASURES}

Vestnik Tomskogo gosudarstvennogo universiteta - Tomsk State University Journal, 2017, 417, $210-213$.

DOI: $10.17223 / 15617793 / 417 / 30$

Tatyana I. Ryakhovskaya, Siberian Institute of Management, Branch of the Russian Academy of National Economy and Public Administration (Novosibirsk, Russian Federation). E-mail: ryahovskaya.ti@gmail.com

Keywords: Russian Federation Constitution; direct action of Constitution; Constitutional Court; legal properties of Constitution; legal activities; protection of Constitution; system of ensuring direct action of Constitution.

The article is devoted to problems of theoretical and methodological foundations of the direct action of the Constitution, the delimitation of the concepts of security and protection of the Constitution. The aim of the research is to analyze the activities of the Constitutional Court of the Russian Federation (particular interest in it is due to its specific legal nature) in the field of ensuring the direct action of the Constitution and, above all, to introduce the idea of ensuring it by security measures. In the author's opinion, the proposed theme is highly relevant in view of the fact that in today's realities, when the Russian Federation is committed to building the rule of law and civil society development based on the core values proclaimed in the Universal Declaration of Human Rights, 1948, and reflected in the 1993 Constitution of Russia, theoretical and methodological foundations of the direct action of the Consti- 
tution and its implementation in the course of legal action require scientific justification. The study analyzed the theoretical (works by D.A. Avdeev, T.I. Aliyev, E.V. Berdnikov, N.S. Bondar, V.D. Zorkin, M.A. Mityukov, V.A. Kryazhkov, L.V. Lazarev, S.A. Savchenko, B.S. Ebzeev) and empirical (the Russian Constitution; the Federal Constitutional Law "On the Constitutional Court of the Russian Federation"; Terms and Definitions of the Constitutional Court of the Russian Federation) material. The methodological basis of the research was the formal-logical method, which allowed to clarify the properties of the Constitution that distinguish it in the statics and dynamics from other normative legal acts; the systematic method used to ensure the comprehension of the system of the direct action of the Constitution and the establishment of regularities in the activities of state authorities and local selfgovernment, thus forming a specific system of state-legal protection and protection of the direct action of constitutional norms. As a result, the author came to a conclusion that ensuring the direct action of the Constitution of the Russian Federation by security measures is essential. It is a specific rather abstract activity, the result of which is to prevent the violation of the principle of the direct action of the Constitution. The legal activity of the Constitutional Court of the Russian Federation in this area is connected with the specification and clarification of the meaning of constitutional provisions. The main criterion for the construction of this "superstructure" of the Constitution is its own rules that fix the basic provisions that require further development and the main directions of the development.

\section{REFERENCES}

1. Avdeev, D.A. (2004) Pravovoy mekhanizm obespecheniya prav i svobod cheloveka i grazhdanina [The legal mechanism for ensuring the rights and freedoms of man and citizen]. Abstract of Law Cand. Diss. Tyumen.

2. Kryazhkov, V.A. \& Lazarev, L.V. (1998) Konstitutsionnaya yustitsiya v Rossiyskoy Federatsii [Constitutional Justice in the Russian Federation]. Moscow: Izd-vo BEK.

3. Ebzeev, B.S. (1994) Konstitutsionnyy Sud Rossiyskoy Federatsii: novaya stranitsa zhizni [The Constitutional Court of the Russian Federation: a new page of life]. Chelovek i zakon. 11. pp. 3-12.

4. Bondar'. N.S. (2006) Resheniya Konstitutsionnogo Suda kak mera svobody i otvetstvennosti [Decisions of the Constitutional Court as a measure of freedom and responsibility]. Konstitutsionnoe i munitsipal'noe pravo. 10. pp. 2-5.

5. Aliev, T.I. \& Berdnikova, E.V. (2013) Konstitutsiya Rossiyskoy Federatsii: predely stabil'nosti i perspektivy modernizatsii [The Constitution of the Russian Federation: limits of stability and prospects of modernization]. Sovremennoe pravo - Modern Law. 12. pp. 9-14.

6. Savchenko, S.A. (2011) Konstitutsionnyy protsess realizatsii norm, zakreplyayushchikh osnovy konstitutsionnogo stroya Rossii [The constitutional process of implementing the norms that establish the foundations of the constitutional system of Russia]. Tyumen: Tyumen State University.

7. Russian Federation. (1995) Opredelenie Konstitutsionnogo Suda RF ot 20 noyabrya 1995 g. № 77-O “Ob otkaze v prinyatii k rassmotreniyu zaprosa gruppy deputatov Gosudarstvennoy Dumy Federal'nogo Sobraniya i zaprosa Verkhovnogo Suda Rossiyskoy Federatsii o proverke konstitutsionnosti ryada polozheniy Federal'nogo zakona ot 21 iyunya 1995 goda “O vyborakh deputatov Gosudarstvennoy Dumy Federal'nogo Sobraniya Rossiyskoy Federatsii"”, [Decree of the Constitutional Court of the Russian Federation of November 20, 1995, No. 77-O "On refusal to accept the request of a group of deputies of the State Duma of the Federal Assembly and the request of the Supreme Court of the Russian Federation to verify the constitutionality of a number of provisions of the Federal Law of June 21, 1995 "On Election of deputies of the State Duma of the Federal Assembly of the Russian Federation”’’]. Sobranie zakonodatel’stva RF [Code of Laws of the Russian Federation]. 1995. № 49. St. 4867.

8. Russian Federation. (1995) Postanovlenie Konstitutsionnogo Suda RF ot 31 oktyabrya 1995 g. № 12-P “Po delu o tolkovanii stat'i 136 Konstitutsii Rossiyskoy Federatsii" [Decree of the Constitutional Court of the Russian Federation of October 31, 1995 No. 12-P "On the case of the interpretation of Article 136 of the Constitution of the Russian Federation"]. Sobranie zakonodatel'stva RF [Code of Laws of the Russian Federation]. 45. Art. 4408.

9. The Constitutional Court of the Russian Federation. [Online] Available from: http://www.ksrf.ru/ru/Decision/Statisticses/Pages/Decision.aspx. (Accessed: 09th April 2016).

10. Mityukov, M.A. \& Barnashov, A.M. (1999) Ocherki konstitutsionnogo pravosudiya (sravnitel'no-pravovoe issledovanie zakonodatel'stva i sudebnoy praktiki) [Essays on constitutional justice (comparative legal study of legislation and jurisprudence)]. Tomsk: Tomsk State University.

11. Ebzeev, B.S. (ed.) (2000) Kommentariy k postanovleniyam Konstitutsionnogo Suda Rossiyskoy Federatsii: $v 2$ t. [Commentary to the decisions of the Constitutional Court of the Russian Federation: in 2 vols]. Vol. 1. Moscow: Yurist".

12. Russian Federation. (1997) Postanovlenie Konstitutsionnogo Suda RF ot 14 iyulya 1997 g. № 12-P "Po delu o tolkovanii soderzhashchegosya v chasti 4 stat'i 66 Konstitutsii Rossiyskoy Federatsii polozheniya o vkhozhdenii avtonomnogo okruga v sostav kraya, oblasti" [Decree of the Constitutional Court of the Russian Federation of July 14, 1997 No. 12-P "On the case of the interpretation of the provision contained in Part 4 of Article 66 of the Constitution of the Russian Federation on the entry of the Autonomous Okrug into a krai, an oblast"]. Sobranie zakonodatel'stva $R F$ [Code of Laws of the Russian Federation]. 29. Art. 3581.

13. Garant.ru. (1995) Opredelenie Konstitutsionnogo Suda ot 28 dekabrya 1995 g. № 137-O “Ob otkaze v prinyatii k rassmotreniyu zaprosa Gosudarstvennoy Dumy Federal'nogo Sobraniya o tolkovanii polozheniy stat'i 80 i chasti 2 stat'i 95 Konstitutsii Rossiyskoy Federatsii”" [Decision of the Constitutional Court of December 28, 1995 No. 137-O "On refusal to accept the request of the State Duma of the Federal Assembly on the interpretation of the provisions of Article 80 and Part 2 of Article 95 of the Constitution of the Russian Federation"]. (Unpublished).

14. Lazarev, L.V. (2003) Pravovye pozitsii Konstitutsionnogo Suda Rossii [Legal positions of the Constitutional Court of Russia]. Moscow: OAO Izdatel'skiy dom "Gorodets"; Formula prava. pp. 131.

15. Zor'kin, V.D. (2011) Konstitutsionno-pravovoe razvitie Rossii [Constitutional and legal development of Russia]. Moscow: Norma; INFRA-M.

Received: 24 March 2017 